\title{
'You can't avoid sex and cigarettes' \\ How Indonesian Muslim mothers teach their children to read billboards
}

\begin{abstract}
Muslim mothers in Indonesia find many roadside billboards confronting, especially those advertising harmful products such as cigarettes or using sexualised images of women. This unease is exacerbated by the fact that during daily commutes neither they nor their children can avoid seeing these billboards. However, while billboards pose a challenge to Islamic sensibilities, some Muslim mothers use these billboards as sites to educate their children about piety, modesty and tolerance. Such reflexive engagement is informed by an ongoing dialectic between mothers' interpretations of Islamic teachings and the realities of contemporary Indonesian media culture. This article explores this dialectic through interviews with Muslim mothers in Semarang, Indonesia.
\end{abstract}

Keywords: advertising, billboards, communication, culture, Indonesia, Islam, Muslim mothers, parenthood, piety, public space, reflexive media engagement, religion

\section{HANNY SAVITRI HARTONO, SHARYN GRAHAM DAVIES and GRAEME MACRAE Massey University and Auckland University of Technology}

\section{Introduction}

DARENTS everywhere are concerned about the wellbeing of their children and protecting them from detrimental influences. One perennial concern is the influence of mass media, especially with the advent of social media content accessible by handheld devices (Buckingham \& Willet, 2013). While there is the potential for parental control over many forms of media, the appropriation of public space by billboards means that exposure is unavoidable (Klein, 2000).

Over the past few decades the combination of new technologies and deregulation have led to an explosion of media in Indonesia (Rakhmani, 2014). For parents, this unprecedented media exposure presents considerable challenges, not least because media often contradict and conflict with cultural and religious values. For 
many Muslim Indonesians this challenge is acutely felt because Islamic teachings are often clear and unambiguous concerning matters of morality, decency and harmfulness (Davies, 2011).

This article explores the experience of Muslim mothers in Indonesia striving to raise pious children in an environment where media often presents un-Islamic messages. For the mothers in this study, roadside billboards proved a particular challenge because of their ubiquity and unavoidability (Webster, 2010). However, while mothers found billboards advertising cigarettes and suggestive clothing confronting, they also provided a site to explore and articulate to their children the meaning of piety and what being a good Muslim entails in practice. We examine ways mothers use two different kinds of billboards in their approach to parenting. First, the mothers use cigarette billboards to teach their children that pious Muslims should not undertake activities that harm oneself or others. Second, they use billboards advertising fashionable clothing to discuss ways of presenting oneself in public that conform to Islamic principles of modesty and propriety.

Given that this article centres on piety it is useful to offer some understanding of what we mean by piety. Piety is a concept derived from the Qur'anic concept of taqwa (Mahmood, 2005, p. 145). Mahmood (2001, p. 212) elucidates taqwa as the condition of being close to God that is attained through 'practices that are both devotional as well as worldly in character.' According to Mahmood (2011, p. 212), piety also involves attention to one's entire self through 'a simultaneous training of the body, emotions, and reason as sites of discipline until the religious virtues acquire the status of embodied habits.' Rinaldo (2008, p. 29) explains that among Muslim women in Indonesia, pious practices are producing a new kind of habitus that distinguishes women by class and approach to religion. In short, piety is the framework by which some Muslim mothers manoeuvre their everyday lives using the Qur'an and 'ahādìt (words and deeds of the Prophet Muhammad) as their guides. In contrast to ultra-orthodox Muslim groups such as Salafi (Hasan, 2007) and Tablighi Jamā'at (Amrullah, 2011), participants in this study can be considered as moderate Muslims. Participants are considered pious as they observe Islamic personal practices, such as praying, reading the Qur'an, and wearing conservative clothing (including three wearing hijāb, the head veil) as part of their daily attire.

\section{Methods}

This article draws on part of a larger study conducted on how Indonesian Muslim mothers engage with media in their daily parenting practices (Hartono, 2017). The larger study collected data through various methods, including 14 in-depth, semi-structured interviews with Muslim mothers, participant observation of a range of events, including Islamic seminars, and engagement with a closed Facebook group established specifically for the purpose of the larger 
study. These methods, conducted by the first author, allowed participants to reflect on their media engagement in their everyday life. The methodological approach taken for the collection of data and its subsequent analysis followed a post-positivist constructionist position and we specifically followed an interpretive descriptive analytical approach that allowed the thoughts of participants to shape the findings (Thorne, 2016).

For this particular article, the data used was collected during four in-depth, face-to-face interviews conducted in 2015 in Indonesia by the first author. The women were selected through a snowballing method and they responded to a call for research participants disseminated through Facebook. The questions for the interviews focused specifically on how the mothers engaged with public billboards and how they negotiated their content in their everyday lives as mothers. The pseudonyms of the four mothers are: Niar, Vina, Hesti and Dani. These women were all well-educated, worked full-time and regarded themselves as pious (bertakwa) Muslims. While data for this article represents the views of just four women, given the wider data collected and our extensive review of literature, it seems likely that the ways they engage with and critique billboards may be typical of pious mothers across Indonesia. At the very least, these findings show that for some Muslim mothers, billboards can be useful pedagogic tools despite the challenges they present.

\section{Mothering}

The concept of parenting, and more specifically mothering, relates to practices of raising children with values, beliefs, motivations and attitudes that parents and wider society deem appropriate. 'Parenting' can be thus seen as a historically and socially situated form of childrearing, a product of late 20th century ideological shifts in understandings of kinship, family and social morality (Faircloth, Hoffman \& Layne, 2013). In Europe, from around 1800, newly expanded medical and educational institutions gave rise to an interest in investigating and improving the care and learning of children (LeVine, 2007). By 1920, Sigmund Freud had influentially argued that parenting had a significant impact on young children, leading to an increase in public interest in childrearing and on what constituted a 'normal' child. Also around this time missionaries and colonial administrations began exploring concepts of good parenting and child development in cross-cultural contexts (e.g. Junod, 1912).

A number of early anthropological studies focused on parenting, childhood and kinship (Faircloth, 2014, LeVine, 2007). Such studies proved important in showing that parenting is 'crucial to the transmission of culture, the development of enculturated persons, the constitution of kinship, family, and household, and the reproduction of society' (Barlow \& Chapin, 2010, p. 324). Early parenting studies include those of Margaret Mead $(1928,1930)$ and Bronislaw Malinowski 
(1929) who both worked in the Asia-Pacific region; although it should be noted that some of Mead's work was later discredited. Such studies showed the diversity of parenting styles and provided material to critique a singular Western worldview. Significantly, much of this anthropological literature showed the important parenting role assumed by fathers (Hewlet, 2008, 2011a, 2011b; Mead 1963) and the various roles taken on by mothers (Bolin, 2006; Konner, 2005, 2007; Liamputtong 2007; Riseman, 1992; Shostak 1981). Much subsequent anthropological work on mothering focused on aspects such as breastfeeding, pregnancy, birth and morality (Hays, 1996; Smyth, 2012; Volk, 2009; Walks, 2011).

Motherhood has played a significant role in the imagination of Indonesia (Danzinger, 1960; Geertz, H. 1961; Khisbiyah, 1992; Subandi, 2011; Swasono, 1998; Zevalkink \& Riksen-Walraven, 2001). The Indonesian state frames a woman's duty as primarily raising and educating her children and as soon as a woman marries she is questioned about when she will have children (Nurmilla, 2009). A common assumption is that while fathers can enjoy their children it is up to mothers to discipline them. Mothers are then judged by their children's behaviour and achievements (Mulder, 1992).

The 1974 Indonesian marriage law positions the husband as head of the household and the wife as homemaker. A woman's status is thus tied to her husband and she is expected to be obedient to him (Doorn-Harder 2006; Srimulyani 2012). Women are positioned as the primary supporter of their husband, providing offspring, caring for and rearing their children, being good housekeepers and guardians of community values (Djajadiningrat-Nieuwenhuis, 1987; Sunidyo, 1996; Sunindyo, 1995; Suryakusuma, 2011). Women must suppress their personal desires and wishes in order to be good mothers (Schleifer, 1986). A woman's natural ability/proclivity (kodrat) is said to be directly based on her biology (fitrah) (Blackburn 2004; Dewi 2012). As such, women are expected to reinforce the natural order of society (Sullivan, 1991; Davies, 2015). Indonesian media consistently reinforce the roles of women as wives and mothers (Brenner 1999) and although these roles are expanding they remain women's core identity (Blackurn, 2004; Yulindrasari \& McGregor, 2011).

Muslim mothers are expected to adhere not only to these national values but also Islamic ones (Ali, 2004; Al-Hashimi, 2000; Al-Joyyousi \& Al-Salim, 2014). The importance of a mother's role in Islam is stressed in hadith (sayings of the Prophet) such as:

A man came to the Prophet and said 'Who among the people is the most worthy of my good companionship? The Prophet said: Your mother. The man said, 'Then who?' The Prophet said: Then your mother. The man further asked, 'Then who?' The Prophet said: Then your mother. The man asked again, 'Then who?' The Prophet said: Then your father (Inside Islam, 2012). 
The Qur'an acknowledges the sacrifice, compassion and service of mothers and promises rewards in the afterlife (Schleifer, 2007). It also provides advice to mothers, including on such practical matters as how long to breastfeed $(\mathrm{Oh}$, 2010). In striving toward these ideals, mothers participating in this study read parenting books, attended seminars, followed fatwa (Islamic rulings/edicts), joined Islamic study circles (pengajian) and Facebook discussions, read Muslim parenting websites and discussed parenting practices with husbands and friends. Birth announcements posted on Facebook often met with replies such as: 'Congratulations! Hopefully your child will be pious (Semoga menjadi anak yang sholeha).'

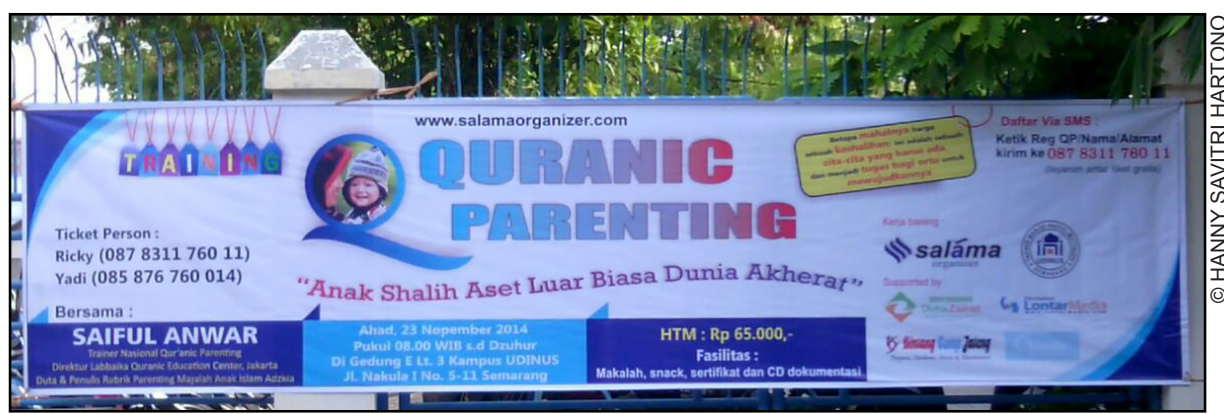

Figure 1: ‘Qur'anic Parenting: Pious Children are Incredible Assets in the Hereafter'.

Women in this study also attended Qur'anic Parenting seminars (Figure 1). Such seminars began with a video revealing the importance of having good morals and manners (akhlak) and of taking care of orphans. Speakers emphasised that mothers should reinforce teachers, especially in terms of Islamic etiquette $(a d a b)$. One example often given was that while school teachers instruct children to eat with the right hand, parents must reinforce this at home and set an example. Seminars emphasised that teachers merely reinforce home teachings and that the primary responsibility for Islamic instruction is held by mothers. Such seminars were open to both parents but fathers rarely attended. At one 2015 seminar attended by 50 participants only eight were fathers. Mothers said they found these seminars enjoyable because they reinforced what they already knew, taught them new things, such as the importance of arising before the early morning prayer, and because they provided them with a sense of comradeship.

Women in this study also used Muslim women's magazines to help them become better mothers. They talked about how these magazines drew on the Qur'an and hadith to address topics such as how to breastfeed during the fasting month, how to use the veil to cover up while breastfeeding, and how fathers can assist mothers (see the magazine Ummi 2013-2014 passim). Participants also spoke of how important it was that babies receive only breastmilk for their first six months (cf. Blum 1999; Lee 2008). Indeed one participant described how 
she would go into the work bathroom and express milk into a water bottle to ensure she could provide her baby with breastmilk.

Over recent decades Indonesia has become increasingly Islamised (Rinaldo, 2013). This increasing Islamisation is a result of various factors. Hefner (1993, p. 13) argues that Islamic revitalisation among middle class Indonesians was sparked by a growing cynicism and resentment towards political elites who unashamedly displayed their wealth and power, and their perceptions of the decline of traditional mores and etiquette. Other authors have framed this move as one of rising Islamic 'consciousness', instead of Islamic 'resurgence' or 'revival' (Brenner 1996). Indeed Brenner suggests that resurgence has the connotation of recapturing the old spirit of embracing Islam as a way of life and thus consciousness is a better work because it connotes embarking upon a new venture, which she argues has been what has happened. After the reformation of 1998, a growing number middle class Indonesians gained access to conservative global Islamic discourses because of the loosening of state censorships on media (Rinaldo, 2011). A key factor in the rise of Islamisation has thus been that during President Suharto's rule (1965-1998), Islam was kept at bay because Suharto worried that a strong Islamic movement would threaten his power. After his forced resignation in 1998, Islamic groups moved to fill much of the power void. As such, Islam is currently driving a moral panic over issues such as sexuality (Davies, 2016).

As a result of this increasing Islamisation, there has been a concomitant rise in the perceived responsibility and obligation of Muslim mothers to raise pious children. In their parenting practices, though, Muslim mothers must also engage with competing demands from the state, secular modernity, Westernisation and the media. While media can help mothers deal with the challenges of contemporary life, media also present challenges to Muslim mothers trying to raise pious children, particularly when media such as billboards cannot be avoided.

\section{Billboards}

Billboards have been used as a form of advertising since at least the early $1800 \mathrm{~s}$ and indeed such was their prevalence that London started regulating billboards in 1837 (Wharton, 2013). While billboard technology has developed significantly with the advent of digital billboards, many remain static (Cronin, 2013) Unlike other media, where there is an element of choice in viewing and for parents some control over their children's access, by merely engaging in urban life people are exposed to images on billboards (Rosewarne, 2007).

Travel in any Indonesian city results in viewing billboards advertising everything from cigarettes to baby formula, scooters to face whitening creams. Billboards compete for space and attention and create what many see as a chaotic streetscape. Such is the resulting visual disorder that some mayors have called for a ban on outdoor advertising (Melanngar Perda 2015). However, billboards 
bring advertising money to local governments and hence there is competing pressure to increase the number of billboards. Billboard regulation is constantly undergoing revision in the battle between profit and aesthetics (Leis, 2015). What has eluded discussion at government level in Indonesia, though, is how religious belief intersects with billboards.

Religion plays a significant role in shaping perceptions of and responses to advertising (Bayraktar, 2012; Farah and El Samad, 2014). Perceptions of and responses to advertising often take the form of critical disapproval of the products advertised and/or the way they are advertised. Mothers in this study talked mostly about two types of billboards: those advertising cigarettes and those employing sexualised images of women. Given that censoring viewing is not a realistic option, how do Muslim mothers in Indonesia engage with billboards they feel reflect lifestyles and values incompatible with piety?

\section{Cigarette billboards}

Estimates suggest that 68 percent of Indonesian men and four percent of Indonesian women smoke cigarettes (World Development Indicators, 2016). It is also estimated that 32 percent of secondary school students aged 13-15 (mostly boys) smoke cigarettes, with 43 percent of people starting to smoke as young as 13 (WHO, 2014). Smoking rates are also high as cigarettes cost only around US\$1.40 a pack.

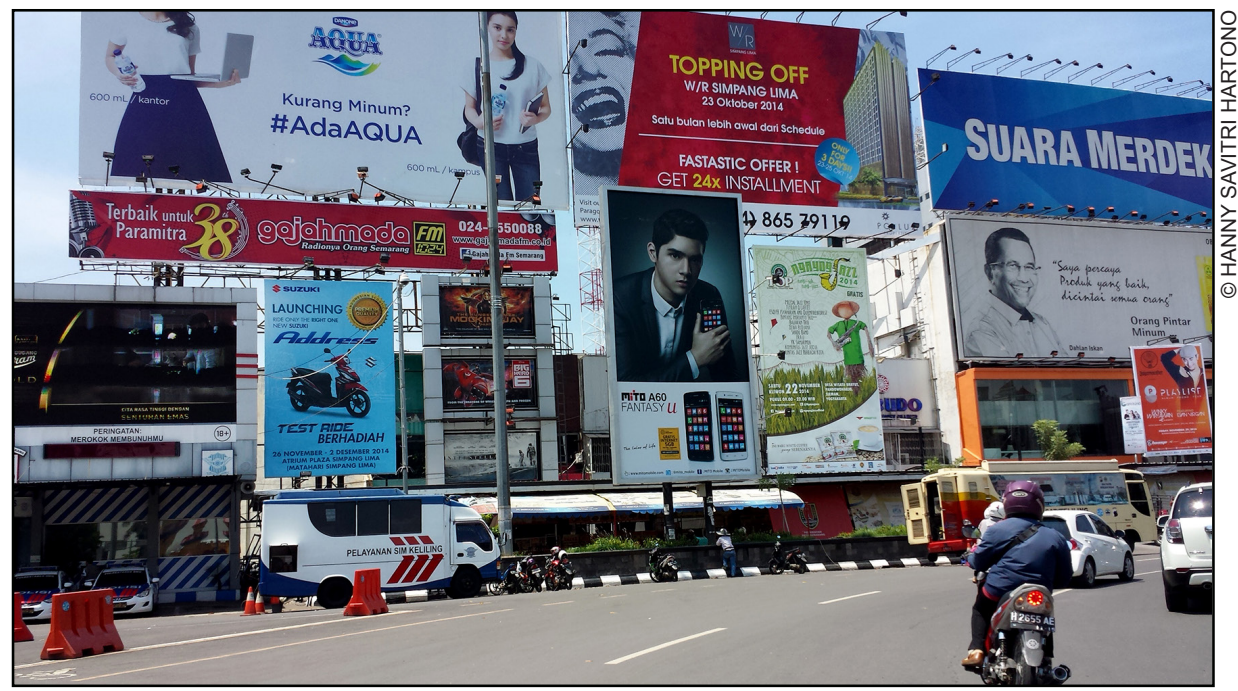

Figure 2: Prolific billboards in an Indonesian city.

The Indonesian government is slowly showing concern for these high rates of smoking but corruption, weak government, the power of tobacco companies and a smoking culture make smoking rates hard to reduce (Harsono, 2011). There was a glimmer of hope in 2014 when the Minister of Health urged a ban 
on cigarette sponsorship for music and sporting events, but this did not eventuate. Jakarta has regulations banning tobacco advertising but they are rarely enforced (Govenor Ahok signs bill, 2016). Some restaurants and universities have no smoking signs but these too are largely ignored. The World Health Organisation has recommended that Indonesia restrict cigarette advertising but cigarette billboards remain prolific on roads, bridges, in front of schools, in house yards and even at police stations (Figure 2). While billboards must include warnings that smoking kills and that you have to be at least 18 years old to smoke, and some also show horrific images of cancerous mouths, these appear only in small font at the bottom of billboards.

Tobacco companies excel at selling their product. Cigarette billboards suggest that if you smoke you will become cool, brave and macho, images particularly persuasive to teenage boys ( $\mathrm{Ng}$, Weinehall \& Ohman 2007). Cigarette companies use English to raise desirability and prestige. Local companies selling clove cigarettes (kretek) sell the idea that smoking kretek preserves a cultural legacy and even that it has health properties (Arnez, 2009; Polzin et al 2007). Cigarette companies sponsor music concerts, such as the 2015 Bon Jovi concert, and give away free cigarettes to audience members (Figure 3). Other popular entertainers, though, such as Kelly Clarkson and Maroon 5, have refused tobacco sponsorship (Siregar, 2010). Tobacco companies have claimed that without their sponsorship music and sports events would collapse (Siregar 2010). Moreover, tobacco companies argue that advertising restrictions violate their constitutional right to advertise legal products (Faizal, 2016).

Tobacco companies are incredibly powerful in Indonesia. Former president Yudhoyono had close links with the Sampoerna tobacco empire which financially supported a national newspaper mouthpiece for Yudhoyono's party (Aditjondro, 2010). Tobacco companies also try to win the hearts and minds of Indonesians by philanthropic works. For instance, Sampoerna has set up a foundation providing scholarships to underprivileged students while Djarum, another tobacco company, has set up a similar foundation to fund health care such as providing free cataract surgery.

In 2009, the Indonesian Ulema Council (MUI) issued a fatwa (religious ruling) that Muslims should not smoke and it classified smoking somewhere between haram (forbidden) and

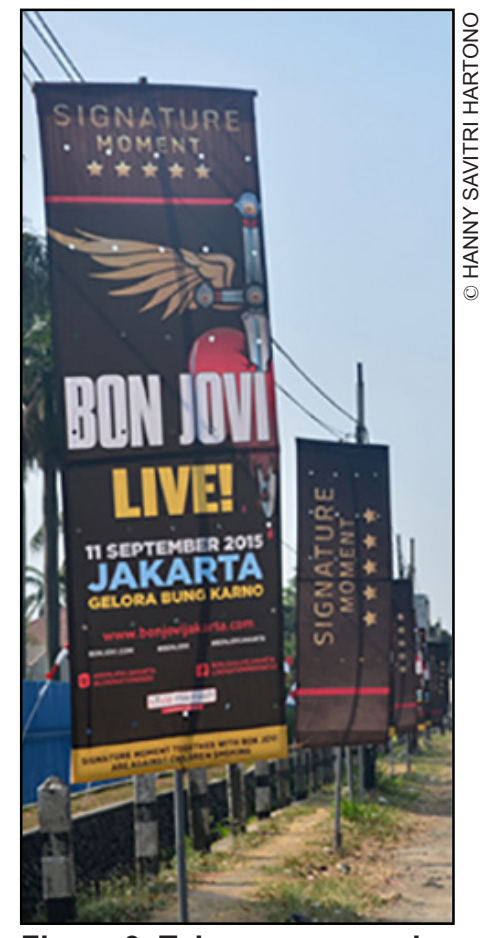

Figure 3: Tobacco companies sponsor music events. 
makruh (discouraged) (Hariyadi, 2010). Other countries have made similar rulings. For instance, Malaysia (Ruban, 2016), Saudi Arabia (Husain 2014) and Egypt (Radwan et al., 2003) have declared smoking haram. Saudi Arabia even declared Mecca and Medina smoke free zones. There is no specific mention of smoking in the Qur'an (Farah \& El Samad, 2014) but MUI issued the fatwa on the basis that the Qur'an prohibits Muslims from harming themselves and since smoking harms, Muslims should not smoke (Ghouri, Atcha \& Sheikh, 2006). The fatwa also drew on Qur'anic injunctions that Muslims should avoid wasting money and should protect others from harm (ibid). Not all Muslim groups in Indonesia agree with MUI's ruling. Nahdlatul Ulama declared smoking as mubah (religiously neutral) while Muhammadiyah declared smoking as neither haram (prohibited) nor halal (permitted). These latter two organisations-Nahdlatul Ulama and Muhammadiyah - are the two largest Islamic organisations in the country and are generally considered moderate organisations, although there are various differences between the two, including Nahdlatul Ulama's political alignment and more conservative approach compared to Muhammadiyah, the older of the two, which is more moderate and non-political. So how do Muslim mothers react to such billboards when teaching their children about piety? We explore this issue after first discussing the other main billboard mothers talked about.

\section{Sexual content billboards}

Another type of billboard that Muslim mothers found confronting was that showing sexual content. Sexual content can be in the form of nudity or revealing dress, showing sexual behaviour such as kissing, or making sexual references using objects or music (Ismail \& Melwar, 2014). Culture and religion mediate responses to sexual content (Ford, LaTour \& Clarke, 2004). In Malaysia, for instance, the state draws on religion to justify prohibiting displays of intimacy and indecency; even models for shampoo products are often posed wearing a head veil (Ismail \& Melewar 2014). In general, though, sexual content is ubiquitous in advertising because sex sells and its use is increasing in Indonesia (Handajani, 2008).

Weddings are big business in Indonesia and billboards advertising wedding services such as florists, hair dressers, cake decorators and entertainers abound in any metropolitan area. Such billboards are also rife with sexual content and thus form a site where commercial and moral imperatives collide. One particular billboard that mothers talked about advertised an upcoming wedding expo entitled 'When East Meets West'. One billboard model appeared in a Western style wedding dress while the other wore a traditional kebaya top and jarik skirt. The clothing for both models was figure hugging, open at the shoulders and revealed cleavage (Figure 4). Both models were tall and slim with fair skin and European features, all of which are associated with wealth, affluence, success, superiority, 
modernity, hygiene and purity (Handajani, 2008; van Leeuwen, 2011). The ideal bride could thus be said to have a persona barat (Western charm) combined with notions of East Asian (Korean and Japanese) beauty (Yulianto, 2014). To be other than this, especially on one's wedding day, may bring shame (Prasetyaningsih, 2007; Saraswati, 2013). So how do Muslim mothers react to such billboards when teaching their children about piety?

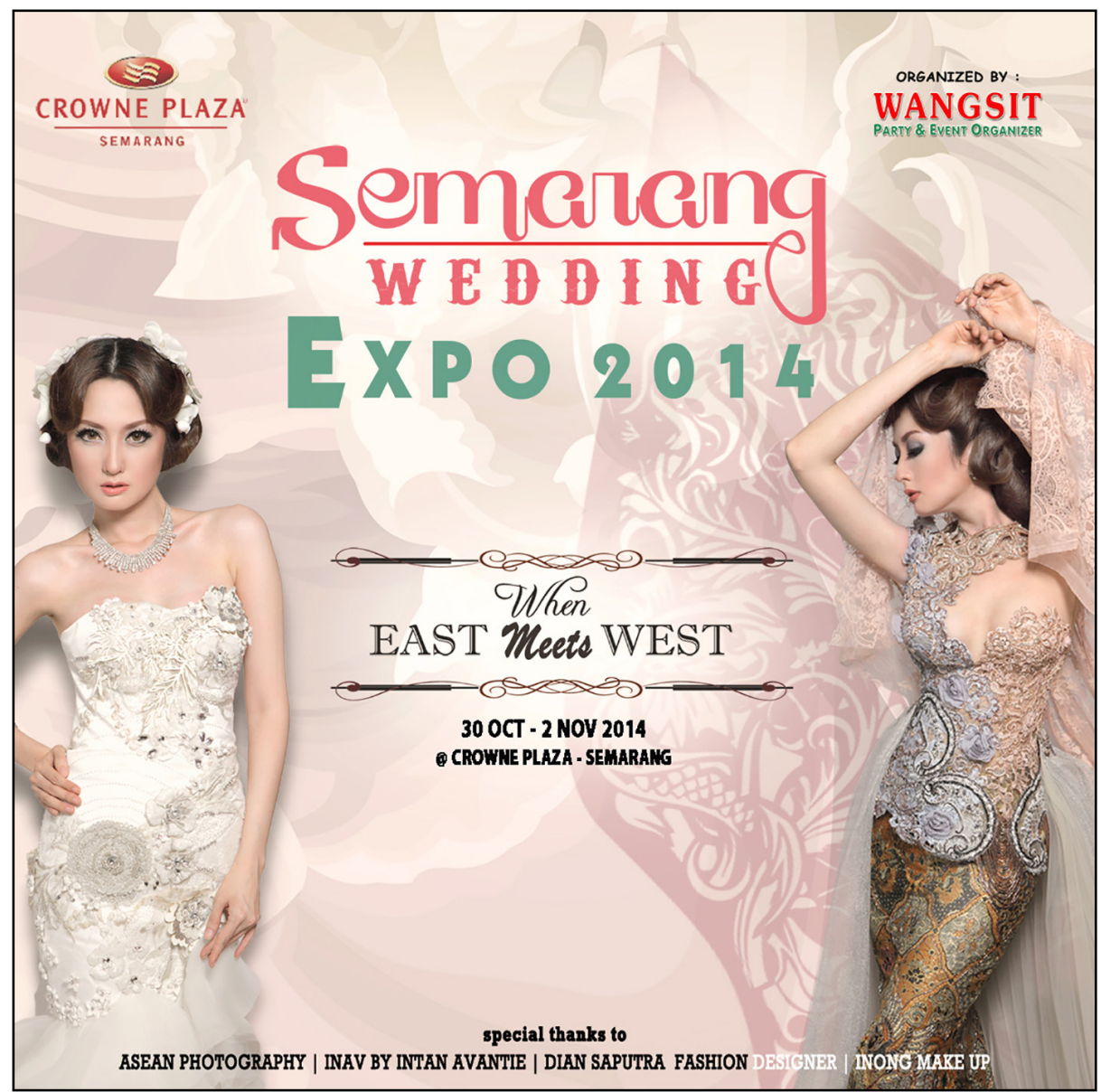

Figure 4: Wedding expo ... Western style and traditional and both revealing.

\section{Muslim mothers and billboards}

While children under six are, in Indonesian thinking, often considered immune to the influence of media because they are durung ngerti (not yet capable of understanding the world around them), after this age parents worry about children's impressionability. While parents teach children appropriate behaviour and values through setting a good example, the presence of billboards selling cigarettes or using sexualised imagery pose challenges. 
For one mother in the study, Niar, cigarette billboards created a sense of unease because of the contradictory messages presented. She noted that billboards frame smoking as a path to creating a smart nation. To this end, one cigarette company, Djarum, advertised that it provided university scholarships to disadvantaged students. Djarum was acting hypocritically in Niar's view because it was profiting from 'selling addiction to the nation's youth.' Rather than creating a smart nation, cigarette smoking created an unhealthy nation. Niar noted that through scholarships Djarum made students feel indebted to the company and thus even when students suffered ill-health they would continue defending the company. Students, who would otherwise be well-placed to agitate against tobacco companies, became activists supporting citizen's rights to smoke. While Niar wanted such billboards banned she finds they provide valuable pedagogic resources to teach her children about the dangers of smoking.

Hesti, another participant, was also concerned about cigarette advertising and its harmful (mudarat) impact on her children. She commented that her sons always notice these billboards because they show masculine role models. Hesti drew on the fatwa against smoking, and on her own judgement and knowledge of Islam, to teach her children that Muslims are forbidden to harm themselves and as such smoking is forbidden.

Mothers in this study also worried about the harmful influence of immodest billboards. Modesty is at the core of both Indonesian and Muslim notions of womanhood. Moreover, the use of human images is questionable in Islam and thus the Prophet Muhammad is not represented in human form-depictions of the Prophet are forbidden in Sunni Islam and permissible only under certain circumstances in Shi'a Islam. For the mothers in this study, then, to see billboards displaying women in revealing clothing, challenged their notions of modesty and piety.

One mother, Vina, spoke of feeling alarmed at the sexual content of billboards, in particular one wedding billboard that was located in front of her daughter's intermediate school. Vina commented that she spent a lot of time mbatin (thinking with the heart instead of the head) about this billboard and how she could teach her children about modesty in the face of such public immodesty. Vina initially found it hard to respond to questions such as 'Why is there a billboard like that, Ma? Why is it being shown? Is it good?' Vina worried that her children would think that because this billboard showed women's aurat (intimate parts of the body, in this case cleavage) they would think they too could show their aurat in public. After consideration, Vina framed her response to her children in terms of the key Islamic tenets of aurat and modesty. She noted that such billboards should be placed in carefully selected positions, not in front of schools. She also told her children that billboards should advertise wedding attire in an attractive way that does not reveal a woman's aurat. Vina used this billboard as a site to 
provoke questions about propriety, dress and woman's bodies and to teach her children how to be good Muslims.

Dani, another participant, also worried about her children's exposure to sexy images on billboards. Dani talked specifically about one billboard that showed a picture of a beautiful DJ dressed in a tank top and shorts. This billboard was placed opposite the Islamic school her daughter attended. One morning upon arriving at school, Dani's daughter asked, 'Ma, shouldn't a tank-top be underwear? Ma, why doesn't she dirangkepi (cover it up)?' Dani then used this billboard as a site of instruction, telling her daughter that according to Islamic belief people should dress decently and cover their aurat. She also used this billboard as a site to teach her daughter about tolerance, noting that other people have different beliefs about modesty, but Muslim women should cover up. Dani's daughter then questioned her about not wearing a veil:

My daughter then said 'Mama, why don't you veil (berkerudung)?' I told
her that 'although I don't wear hijäb (veil), I always dress sopan (politely/
modestly). Kak (older sibling), when I go to your school I always wear long
trousers with a loose shirt. So even though I don't wear a veil (berkerudung)
I am covered. One day I will definitely wear it, Kak, but you never see
me wear a tank-top. Mama always dresses neatly. I am always covered.'

Despite Dani's frustration over images displaying women's aurat, especially those placed close to schools, she uses these billboards as sites to critically reflect what it means to be a pious Muslim. Dani teaches her daughter about modesty through such billboards. Interestingly, Dani referred to her daughter as Kak (elder sibling) to reinforce her daughter's position as role model and teacher for her younger siblings in their respective journeys toward piety.

\section{Conclusion}

This article explored ways Muslim mothers teach piety and raise good Muslim subjects in a landscape of un-Islamic billboards. We revealed that while billboards often provoke unsettling feelings, mothers frame their engagement using religious understandings of aurat and modesty, showing that while media are embedded in everyday life, viewers bring interpretive meaning (Lembo 2000). In particular, mothers in this study used Islamic knowledge to frame billboards in ways instructive for their children, providing them with a way to frame proper Muslim citizenship and sexual morality. Furthermore, discussions created opportunities for mothers to emphasise teachings and explain why certain things are important to them as Muslims. By contrasting religious understanding of fatwa, health, aurat and modesty with the billboards, mothers legitimated Islamic constructions of health, femininity, propriety, virtue and modernity. By embodying such a persona, mothers created an image for 
their children of a morally superior self (cf. Parker 2008). Moreover, billboards motivated mothers to demonstrate proper femininity and sexual morality and supported their ideals about the body, health and propriety. Billboards also provided a site for mothers to discuss with their children the notion that piety is not something you simply possess but rather obtaining it is a lifelong journey.

Mothers in this study demonstrated a capacity to critically reflect on advertising billboards and frame them against their own religious convictions. Their high levels of religious education assisted in this agentic process of reflectivity (Sakai \& Fauzia, 2014). Indeed, agency is not a 'synonym for resistance to relations' but can be seen as 'a capacity for action that historically specific relations of subordination enable and create (Mahmood, 2001 p. 203). Muslim mothers thus showed agency in the sense of having a "capacity to negotiate with power in whatever form - as complicity, compromise, deviance or resistance — and with whatever motivation ... intentional or unintentional, voluntary or involuntary, self-expression, self-interest or group interest' (Parker \& Dales, 2014, p.165). Muslim mothers in this study were thus able to make meaning and identity from these billboards and develop pragmatic responses in the production of their own and their children's moral subjectivity. Such reflectivity enabled these Muslim mothers to use their ongoing striving for piety to provide moral guidance for their children via-a-vis confronting billboards. This article thus starts the conversation about how Muslim mothers engage with media such as billboards and we look forward to seeing more research that explores the varied ways in which mothers, and indeed fathers and other caregivers, use media as sites for education across Indonesia's diverse geographic and economic spectrum.

\section{References}

Aditjondro, G. (2010). Membongkar gurita Cikeas: Di balik skandal Bank Century. Jakarta: Galangpress Group

Alī Al-Hāshimī, M. (2000). The ideal Muslimah: The true Islamic personality of the Muslim woman as defined in the Qur'an and Sunnah. Riyadh, Saudi Arabia: International Islamic Publishing House.

Al-Jayyousi, G. F., Roy, R. N., \& Al-Salim, F. (2014). Muslim mothering and migration. International Journal of Education and Social Science, 1(4), 41-49.

Ali, S. M. (2004). The position of women in Islam: A progressive view. Albany, NY: State University of New York Press.

Amrullah, E. F. (2011). Seeking sanctuary in 'the age of disorder': Women in contemporary Tablighi Jamā 'at. Contemporary Islam, 5(2), 135-160.

Arnez, M. 2009. Empowering women through Islam: Fatayat NU Between Tradition and Change. Journal of Islamic Studies, 21(1), 59-88.

Blackburn, S. (2004). Women and the state in modern Indonesia. Cambridge, UK: Cambridge University Press.

Barlow, K. \& Chapin, B. L. (2010). The practice of mothering: An introduction. Ethos, 38(4), 324-338. 
Bayraktar, A. (2012). Does sexuality in ads work for everyone: Muslim consumers' reactions to sexuality in ads. Review of Business \& Finance Case Studies, 3(1), 53-60.

Blum, L. M. (1999). At the breast: Ideologies of breastfeeding and motherhood in the contemporary United States. Boston: Beacon.

Bolin, I. (2006). Growing up in a culture of respect: Child rearing in highland Peru. Austin, TX: University of Texas Press.

Buckingham, D., Willett, R. (2013). Digital generations: Children, young people, and the new media. London, UK: Routledge.

Brenner, S. (1996). Reconstructing self and society: Javanese Muslim women and the 'the veil'. American Ethnologist, 23(4), 673-697.

Brenner, S. (1999). On the public intimacy of the New Order: Images of women in the popular Indonesian print media. Indonesia, 67, 13-37.

Cronin, A. (2013). Publics and publicity: outdoor advertising and urban space. In Public Space, Media Space (pp. 265-276). London, UK: Palgrave Macmillan.

Danzinger, K. (1960). Parental demands and social class in Java, Indonesia. The Journal of Social Psychology, 51, 75-86.

Davies, S. D. (2010). Gender diversity in Indonesia, sexuality, Islam and queer selves, London, UK: Routledge.

Davies, S. G. (2015). Surveilling sexuality in Indonesia. In L. R. Bennett and S. G. Davies (Eds.), Sex and sexuality in Indonesia: Sexual politics, diversity and representations in the reformasi era (pp. 30-61). London, UK: Routledge.

Davies, S. G. (2016). Indonesian 'tolerance' under strain as anti-LGBT furore grows, Asian Currents, available at: http://asaa.asn.au/indonesian-tolerance-under-strain-asanti-lgbt-furore-grows/

Dewi, K. H. (2012). Javanese women and Islam: Identity formation since the twentieth century. Southeast Asian Studies, 1(1), 109-140.

Djajadiningrat-Nieuwenhuis, M. (1987). Ibuism and priyayisation: Path to power? In E. Locher-Scholter \& A. Niehof (Eds.), Indonesian women in focus: Past and present notions (pp. 43-51). Dordrecht, the Netherlands: Foris Publications.

Doorn-Harder, P. v. (2006). Women shaping Islam: Indonesian women reading the Qur'an. Urbana, IL: University of Illinois Press.

Faircloth, C. (2014). Parenting: Kinship, expertise, and anxiety. Journal of Family Issues. doi: $10.1177 / 0192513 X 14533546$

Faircloth, C., Hoffman, D. M., \& L. L. Layne (2013). Introduction. In C. Faircloth, D. M. Hoffman and L. L. Layne (Eds.), Parenting in global perspective: Negotiating ideologies of kinship, self and politics (pp. 1-17). London, UK: Routledge.

Faizal, E. (2016). Cigarette ad ban gets irate manufacturers in a puff. www.thejakartapost. com/news/2016/03/21/cigarette-ad-ban-gets-irate-manufacturers-a-puff.html

Farah M., El Samad, L. (2014). The effects of religion and religiosity on advertisement assessment among Lebanese consumers. Journal of International Consumer Marketing, 26(4), 344-369.

Ford, J., LaTour, M, Clarke, Irvine, (2004). A prescriptive essay concerning sex role portrayals in international advertising contexts. American Business Review, 22(1), 42-56.

Geertz, H. (1961). The Javanese family: A study of kinship and socialization. New York, NY: The Free Press of Glencoe, Inc.

Ghouri, N. M. Atcha and A. Sheikh (2006). Influence of Islam on smoking among Muslims. British Medical Journal. doi.org/10.1136/bmj.332.7536.291

Governor Ahok signs bill (2016, January 28). Governor Ahok signs bill banning 'all' outdoor and indoor tobacco advertising in Jakarta. Coconuts Jakarta. https://coconuts. 
co/jakarta/news/governor-ahok-signs-bill-banning-all-outdoor-and-indoor-tobaccoadvertising-jakarta/

Handajani, S. (2008). Western inscriptions on Indonesian bodies: Representations of adolescents in Indonesian female teen magazines'. Intersections: Gender and Sexuality in Asia and the Pacific, 18, October.

Hariyadi, M. (2010). Indonesian Islamic organization issues a fatwa against smoking. www.asianews.it/news-en/Indonesian-Islamic-organization-issues-a-fatwa-againstsmoking-17838.html

Harsono, A. (2011). Public health suffers as Indonesia ignores calls for tobacco reform. www.icij.org/node/28/public-health-suffers-indonesia-ignores-calls-tobacco-reform

Hartono, V. (2017). Indonesian Muslim mothers and reflexive media engagement: An ethnographic study. Unpublished PhD thesis. Massey University, Auckland, New Zealand.

Hasan, N. (2007). The Salafi movement in Indonesia: Transnational dynamic and local development. Comparative Studies of South Asia, Africa and Middle East, 27(1), 83-94.

Hays, S. (1996). The cultural contradictions of motherhood. New Haven, CT: Yale University Press.

Hefner, R. W. (1993). Islam, state, and civil society: ICMI and the struggle for the Indonesian middle class. Indonesia, 56, 1-35.

Hewlet, B. S. (2008). Fathers and infants among Aka pygmies. In R. A. LeVine \& R. S. New (Eds.), Anthropology and child development: A cross-cultural reader (pp. 84-99). Malden, MA: Blackwell Publishing.

Hewlet, B. S. (Ed.). (2011a). Father-child relations: Cultural and biosocial contexts. New Brunswick, NJ: Aldine Transaction.

Hewlet, B. S. (2011b). Husband-wife reciprocity and the father-infant relationship among Aka pygmies. In B. S. Hewlett (Ed.), Father-child relations: Cultural and biosocial contexts (pp. 153-176). New Brunswick, NJ: Aldine Transaction.

Husain, R. (2014) Saudis ban smoking, hookahs, tobacco in Islam's holiest cities. www. washingtontimes.com/news/2014/oct/14/rahat-husain-saudis-ban-smoking-hookahstobacco-is/

Inside Islam (2012). Available at: https://insideislam.wisc.edu/2012/05/the-importanceof-the-mother-in-islam/

Ismail A. \& Melwar, T. (2014) Attitude of Muslim consumers toward sex appeal in advertising: A comparative study between subcultures in Malaysia. Journal of Promotion Management, 20(5), 553-570.

Junod, H. (1912). The life in a South African tribe. Neuchatel, Switzerland: Imprimerie Attinger Freres.

Khisbiyah, Y. (1992). Domestic roles of employed mothers in Indonesian dual-earner families: Housework and child care in socio-cultural context. Unpublished masters thesis. University of Massachusetts, Lowell, United States.

Kitzinger, S. (1978). Women as mothers. Oxford, UK: Martin Robertson \& Co. Klein, N. (2000). No logo: Taking aim at the brand bullies. New York: Picador.

Konner, M. J. (1977). Infancy among the Kalahari desert san. In P. H. Leiderman, S. Tulkin, \& A. Rosenfeld (Eds.), Culture and infancy: Variations in the human experience (pp. 287-293; 321-328). New York, NY: Academic Press.

Konner, M. (2005). Hunter-gatherer infancy and childhood: The !Kung and others. In B. S. Hewlett \& M. E. Lamb (Eds.), Hunter-gatherer childhoods: evolutionary, developmental \& cultural perspectives (pp. 19-64). New Brunswick, NJ: Aldine Transaction. Konner, M. J. (2008). Infant care in the Kalahari desert. In R. A. LeVine \& R. S. New 
(Eds.), Anthropology and child development: A cross-cultural reader (pp. 66-72). Malden, MA: Blackwell Publishing.

Leis, M (2015). Tobacco smoking among Peking University students—-smoking as a resistance, lack of information on health problems, or a societal norm? A case-study in Peking University with students aged 18-28. https://lup.lub.lu.se/student-papers/ search/publication/8054241

Lee, E. J. (2008). Living with risk in the age of 'intensive motherhood': Maternal identity and infant feeding. Health Risk \& Society, 10(5), 467-477.

Lembo (2000). Thinking through television. Cambridge, UK: Cambridge University press.

LeVine, R. A. (2007). Ethnographic studies of childhood: A historical overview. American Anthropologist, 109(2), 247-260.

Liamputtong, P. (Ed.). (2007). Reproduction, childbearing and motherhood: A crosscultural perspective. New York, NY: NOVA.

Mahmood, S. (2001). Feminist theory, embodiment, and the docile agent: Some reflections on the Egyptian Islamic revival. Cultural Anthropology, 16(2), 202-236.

Mahmood, S. (2005). Politics of piety: The Islamic revival and the feminist subject. Princeton, NJ: Princeton University Press.

Malinowski, B. (1929). The sexual life of the savages in north western Melanesia. London, UK: Routledge.

Mead, M. (1928). Samoan children at work and play. Natural History, $28,301$.

Mead, M. (1963). Growing up in New Guinea. Harmondsworth, UK: Penguin Books. (Original work published 1930)

Mead, M. (1975). Coming of age in Samoa. Harmondsworth, UK: Penguin Books. (Original work published 1928)

Melanngar Perda 2015. Melanggar Perda, Ratusan Spanduk Dicopot. Metro Semarang. 31 March. Available at: http://metrosemarang.com/melanggar-perda-ratusan-spandukdicopot.

Mulder, N. (1992). Individual and society in Java: A cultural analysis (2nd ed). Yogyakarta, Indonesia: Gadjah Mada University Press.

Nastiti, (2014). www.facebook.com/Nastiti-Wedding-Organizer-280718821970860/.

Ng, N., L Weinehall, A. Öhman. (2007). 'If I don't smoke, I'm not a real man'-Indonesian teenage boys' views about smoking. Health Educ Res., 22 (6), 794-804.

Nurmila, N. (2009). Women, Islam and everyday life: Renegotiating polygamy in Indonesia. London, UK: Routledge.

Oh, I. (2010). Motherhood in Christianity and Islam: Critiques, realities, and possibilities. Journal of Religious Ethics, 38(4), 638-653.

Parker, L. (2008). To cover the aurat: Veiling, sexual morality and agency among the Muslim Minangkabau, Indonesia. Intersections: Gender and Sexuality in Asia and the Pacific, 16. http://intersections.anu.edu.au/issue16_contents.htm

Parker, L. Dales, L. (2014). The everyday agency of women in Asia. Asian Studies Review, 38(2): 164-167.

Polzin, G, S. Stanfill, C. Brown, D. Ashley. (2007). Determination of eugenol, anethole, and coumarin in the mainstream cigarette smoke of Indonesian clove cigarettes. Food and Chemical Toxicology, 45(10), 48-53.

Prasetyaningsih, L. A. S. (2007). The maze of gaze: The color of beauty in transnational Indonesia. Unpublished PhD dissertation. University of Maryland, College Park, United States.

Radwan, GN., Israel, E., El-Setouh, M. (2003). Impact of religious rulings (fatwa) on smoking. Journal of the Egyptian Society of Parasitology, 33(3 Suppl):1087-1101 
Rakhmani, I. (2014). Mainstream Islam: Television industry practice and trends in Indonesian sinetron. Asian Journal of Social Science, 42(3/4), 435-466.

Riesman, P. (1992). First find your child a good mother: The construction of self in two African communities. New Brunswick, NJ: Rutgers University Press.

Rinaldo, R. (2008). Muslim women, middle class habitus, and modernity in Indonesia. Contemporary Islam, 2(1), 23-39.

Rinaldo, R. (2011). Muslim women, moral visions: Globalization and gender controversies in Indonesia. Qualitative Sociology, 34(4), 539-560.

Rinaldo, R. (2013). Mobilizing piety: Islam and feminism in Indonesia. Oxford: Oxford University Press.

Rosewarne, L. (2007). Pin-ups in public space: sexist outdoor advertising as sexual harassment. Women's Studies International Forum, 30(4), 313-325

Ruban, A. (2016). Cigarettes are 'haram' too, group says after Malacca bans vaping-See more at: www.themalaymailonline.com/malaysia/article/cigarettes-are-haram-toogroup-says-after-malacca-bans-vaping\#sthash.j6QjuxNX.dpuf

Sakai, M., A Fauzia. (2014). Islamic orientations in contemporary Indonesia: Islamism on the rise? Asian Ethnicity, 15(1), 41-61.

Saraswati, A. (2013). Seeing beauty, sensing race in transnational Indonesia. Honolulu, HA: Hawai'i University Press.

Schleifer, A. (1986). Motherhood in Islam. Cambridge, UK: The Islamic Academy.

Schleifer, A. (2007). Respect for the mother in Islam. In V. G. Henry-Blakemore (Ed.), Voices of life: Family, home, and society (pp. 93-105). Westport, CT: Praeger.

Siregar, L. (2010, September 3). Upin and Ipin win hearts and minds. Jakarta Globe. Retrieved from http://jakartaglobe.beritasatu.com/archive/upin-and-ipin-win-heartsand-minds/

Shostak, M. (1981). Nisa: The life and words of a !Kung woman. New York: Vintage Books.

Smyth, L. (2012). The demands of motherhood: Agents, roles and recognition. New York: Palgrave Macmillan.

Srimulyani, E. (2012). Women from traditional Islamic educational institutions in Indonesia: Negotiating public spaces. Amsterdam, Netherlands: Amsterdam University Press.

Sullivan, N. (1991). Gender and politics in Indonesia. In M. Stivens (Ed.), Why Gender Matter in Southeast Asian Politics, Monash papers on Southeast Asia, No. 23, Melbourne: Monash University.

Subandi, M. A. (2011). Family expressed emotion in a Javanese cultural context. Culture, Medicine, and Psychiatry, 35(3), 331-346.

Sunindyo, S. (1995). Gender discourse on television. In V. M. Hooker (Ed.), Culture and society in New Order Indonesia (pp. 134-148). Kuala Lumpur, Malaysia: Oxford University Press.

Sunindyo, S. (1996). Murder, gender, and the media. In L. J. Sears (Ed.), Fantasizing the feminine in Indonesia (pp. 120-139). Durham: Duke University Press.

Suryakusuma, J. I. (1996). The state and sexuality in New Order Indonesia. In L. J. Sears (Ed.), Fantasizing the feminine in Indonesia (pp. 92-119). Durham, NC: Duke University Press.

Suryakusuma, J. (2011). State ibuism: The social construction of womanhood in new order Indonesia. Depok, West Java: Komunitas Bambu.

Swasono, M. F. (1998) (Ed.). Kehamilan, kelahiran, perawatan ibu dan bayi dalam konteks budaya [Pregnancy, birth and mother's and baby's care in cultural context]. Jakarta: Universitas Indonesia. 
Thorne, S. (2016). Interpretive descriptive. New York, NY: Routledge.

Ummi. (2013). Ibu menyusui ikut berpuasa? Mampu, kok! [Breastfeeding mums fasting? They can do it!]. Retrieved from http://ummi-online.com/ibu-menyusui-ikutberpuasa-mampu-kok.html

Ummi. (2014). Shafiq Pontoh: 'All Out'untuk ASI! [Shafiq Pontoh: 'All out' for breastfeeding!]. Retrieved from http://ummi-online.com/shafiq-pontoh-all-out-untuk-asi. html

Ummi. (2015). Cara merawat anak dimulai saat bayi, pentingnya pemberian ASI bagi pembentukan sifat genetik anak [Childrearing starts from baby, the importance of breastfeeding for forming child's genetic characteristics]. Retrieved from http://www. ummi-online.com/cara-merawat-anak-dimulai-saat-bayi-pentingnya-pemberian-asibagi-pembentukan-sifat-genetik-anak.html

van Leeuwen, T. (2011). The language of colour. London, UK: Routledge.

Volk, L. (2009). Kull wahad la haalad: Feelings of isolation and distress among Yemeni immigrant women in San Francisco's tenderloin. Medical Anthropology Quarterly, 23(4), 397-416.

Walks, M. (2011). Introduction: Identifying and anthropology of mothering. In M. Walks \& N. McPherson (Eds.). An anthropology of mothering (pp. 1-47). Bradford, UK: Demeter Press.

Webster, T.W. (2010). Pergaulan bebas and gendered youth culture in Indonesia. Unpublished PhD Thesis, Murdoch University, Western Australia. research-repository. uwa.edu.au/files/.../Wright_Webster_Tracy_2010.pdf

Wharton (2015). Critical approaches to advertising. London, UK: Routledge.

WHO. (2014). http://www.who.int/tobacco/surveillance/policy/country profile/idn.pdf

World Development Indicators. (2016). https://openknowledge.worldbank.org/bitstream/ handle/10986/23969/9781464806834.pdf

Yulianto, B. (2014). Festival budaya kotagede 2014. Radio Republik Indonesia, 14 October. http://rri.co.id/yogyakarta/post/berita/111012/seni_budaya/festival_budaya_kotagede_2014.html

Yulindrasari, H. \& McGregor, K. (2011). Contemporary discourses of motherhood and fatherhood in Ayahbunda, a middle-class Indonesian parenting magazine. Marriage \& Family Review, 47, 605-624.

Zevalkink, J. \& Riksen-Walvaren, J. M. (2001). Parenting in Indonesia: Inter- and intracultural differences in mothers' interactions with their young children. International Journal of Behavioral Development, 25 (2), 167-175.

Dr Hanny Savitri (Vitri) Hartono was working on this text as part of her PhD when she died suddenly in February 2017. As her supervisors, Dr Sharyn Graham Davies of Auckland University of Technology and Dr Graeme Macrae of Massey University, have reworked this material for publication, keeping the ethnographic data and much of the literature cited and developing Vitri's argument. While this article differs somewhat from the thesis, we trust it remains faithful to Vitri's intention. Vitri was posthumously awarded her PhD by Massey University in 2017. 